\title{
Mathematical Simulation of Forest Fuel Pyrolysis in One-Dimensional Statement Taking into Account Soot Formation
}

\author{
Nikolay Baranovskiy *(D) and Viktoriya Kirienko
}

check for updates

Citation: Baranovskiy, N.; Kirienko, V. Mathematical Simulation of Forest Fuel Pyrolysis in One-Dimensional Statement Taking into Account Soot Formation. Processes 2021, 9, 1616. https://doi.org/10.3390/pr9091616

Academic Editors: Antonio Galgano and Carmen Branca

Received: 28 July 2021

Accepted: 3 September 2021

Published: 8 September 2021

Publisher's Note: MDPI stays neutral with regard to jurisdictional claims in published maps and institutional affiliations.

Copyright: (C) 2021 by the authors. Licensee MDPI, Basel, Switzerland. This article is an open access article distributed under the terms and conditions of the Creative Commons Attribution (CC BY) license (https:/ / creativecommons.org/licenses/by/ $4.0 /)$.
School of Energy and Power Engineering, Tomsk Polytechnic University, 634050 Tomsk, Russia; kirienkvik@gmail.com

* Correspondence: firedanger@yandex.ru

Abstract: Pyrolysis (thermal decomposition) is considered as the most important stage of a forest fire before direct forest fuel ignition. This process is accompanied by soot particle formation. Such particles have a negative impact on public health in the vicinity of forest fires. The purpose of this article was to investigate the heat and mass transfer process occurring in a typical forest fuel element (birch leaf). The pyrolysis and soot formation processes were taken into account, and various forest fire scenarios were considered. Computational experiments were carried out using the high-level programming language Delphi. Heat and mass transfer processes were described by nonlinear nonstationary differential heat conduction equations with corresponding initial and boundary conditions. The differential equations were solved by the finite difference method. Nonlinearity was resolved using a simple iteration. The main results of the research were (1) physical and mathematical models proposed for modeling forest fuel pyrolysis, taking into account soot formation and conditions corresponding to various forest fires; (2) a computer program coded in the high-level programming language Delphi; (3) the obtained temperature distributions over leaf thickness; (4) volume fractions obtained for various components dependent on time and space coordinates. The qualitative analysis of the dependencies showed that the temperature distributions in the birch leaf structure are similar for all forest fire types and differ only in absolute value. The intensity of the soot formation process directly depends on the forest fire type. The presented results should be useful in predicting and assessing forest fire danger, including near the facilities of the Russian Railways.

Keywords: mathematical simulation; forest fuel; pyrolysis; soot formation; forest fire; ignition

\section{Introduction}

Forest fires significantly influence the health of people in forested areas [1,2]. A large variety of pollutants are produced during forest fires [3], including carbonaceous soot particles [4]. As a result of atmospheric transport, such particles can end up in the air [5] that people breathe. There can be different scenarios for human exposure to polluted air [6,7]. However, wherever people are, smoke or soot particles have an effect that can result in cardiorespiratory diseases [8] and mortality [9]. Forest fire is a multistage process [10], including several stages, namely, forest fuel inert heating, moisture evaporation, thermal decomposition, flame combustion of gaseous pyrolysis products, and coke residue afterburning. Even at the pyrolysis stage, a certain amount of soot is produced [11]. Therefore, it is important to understand the heat and mass transfer processes in the forest fuel element, accompanied by soot particle formation.

Pyrolysis is a thermochemical process during which biomass is converted into a solid with a high carbon content and volatility when heated in the absence of oxygen [12]. In forest fires, oxidative pyrolysis is implied. Typical forest fuel mainly consists of cellulose (about 50\%), hemicellulose (about 10-40\%) and lignin (about 10-40\%) [12]. 
Different types of pyrolysis models that take into account different chemical reactions and approaches have been developed. Theories of macroscopic kinetic models are based on theories of homogeneous reaction kinetics. Here, instead of reagent concentrations, a solid phase transformation is used, since pyrolysis is a thermally stimulated heterogeneous reaction. Arrhenius theory is used to describe the reaction rate $\mathrm{k}(\mathrm{T})$, pre-exponential factor A and activation energy E [13].

The kinetic or reaction model refers to the different types of reactions that occur during biomass pyrolysis. According to the reaction mechanism, these models are divided into lumped and distributed models. The distributed activation energy model (DAEM) assumes that pyrolysis occurs through numerous independent parallel reactions with different activation energies. The activation energy distributions can be described by a continuous function [13]. In lumped models, various biomass components and reaction products are combined into three main product classes (gas, tar and char) via one-step or multi-step reactions. Several kinetic schemes have been proposed for the primary biomass and volatile product decomposition (mainly tar or hydrocarbons with a higher molecular weight) [12]. Such models do not include information about the reaction pathways and are black box models [13]. Different approaches to describe the order of reactions can be found in literature. For example, pyrolysis reactions can proceed in a sequential competitive [14] or parallel way [15], or according to biomass pseudocomponent behavior [16].

Numerical study of biomass pyrolysis requires kinetic parameter input data. Therefore, experimental studies of this process are required to determine these parameters as well as peculiarities of the physico-chemical mechanism. Experimental work is aimed at studying the pyrolysis characteristics of various species of plants and wood under various external conditions [17-22]. It should be noted that the pyrolysis process is influenced by the biomass type and species (living or dead), heat transfer mechanism, and the atmosphere in which this process takes place. It also emphasizes the need for a transition to models of multistage reactions, since in this case it is possible to determine the mass loss rate more accurately. Experimental studies devoted to the investigation of the biomass ignition and combustion processes are also of great importance. The obtained data make it possible to determine the typical temperatures and ignition delay times of the samples and to estimate the regularities of this process [23-32]. It was noted that the ignition of living and dead fuels occurs in different ways due to the moisture content in the samples. The existing theoretical and experimental basis allows a numerical experiment to study the pyrolysis process on specific types of plants or wood [33-37].

When studying the processes occurring with forest fuel during a fire, close attention should be paid to the formation of smoke particles. The composition of the combustion products formed depends on the temperature and pressure of combustion, as well as on the mass fraction of chemical elements that make up the forest fuel. The ratio of the mass of solid particles of smoke aerosol to the mass of burnt forest material varies depending on the characteristics of the fire. According to some experimental data, when 1 ton of forest fuels is burned, about $24 \mathrm{~kg}$ of solid particles enter the atmosphere [38].

Aerosol smoke emissions include three types of chemicals [39]:

(a) substances of mineral and soil origin (3-15\% of the total mass of smoke emission) in the form of chemical oxides and salts of elements.

(b) organic substances such as thermally decomposed biomass components (60-80\% of the total smoke emission mass)

(c) elemental carbon (7-15\% of the total smoke emission mass)

Forest fuel combustion is the main reason for fine particle emissions into the atmosphere [40]. The particles size and distribution in space depends on the fuel type, combustion environment and conditions, and measurement technologies. A rapid increase in particle size occurs immediately after the emission of smoke particles. The predominant proportion of particulate matter emitted into the atmosphere is carbonaceous material, which consists of organic and elemental carbon. In addition to organic carbon, solid particles can also be levoglucosan-like species. All smoke components have different optical 
properties [40]. During a flaming fire, relatively more soot particles are released than in the case of a smoldering fire [40].

There are many papers in literature devoted to the investigation of the features of soot particles [41-45]. In this work, the pollutant emissions generated during forest fuel combustion were characterized. Different biomass species were selected as objects of the study. As a result, characteristics such as the size spectrum, chemical composition, rate of formation, and emission factors were determined. It was established that the biomass type has a significant impact on the amount and composition of emissions. This can be explained by the different elemental composition and moisture of the samples.

In paper [46], the authors presented the best estimate of the emission factor for forest fires in the United States. However, significant gaps in current knowledge exist in four areas: forest fires in temperate forests, smoldering residual combustion, aerosol formation and nitrogenous compounds. The first area is specific to the United States, and the last three refer to open burning of forest fuel in many regions of the world.

Thus, the study of the processes of pyrolysis and the formation of soot particles is of great interest. The aim of this research was the mathematical modeling of heat and mass transfer processes in a typical forest fuel element (birch leaf), taking into account thermal decomposition and soot particle formation.

\section{Materials and Methods}

All of the calculations were performed using the RAD Studio software. Heat conduction equations were used to describe heat and mass transfer in a forest fuel sample [47]:

$$
\rho c \frac{\partial T}{\partial t}=\lambda \frac{\partial^{2} T}{\partial z^{2}}+Q(t, z)
$$

The finite difference method was used for solving differential equations. The principle of this method is in using finite-difference approximations instead of derivatives in the equation. Thus, the investigation area was represented as a finite-difference grid, consisted of nodes. Finite-difference analogues were used for the replacement of the partial derivatives of the equation. As a result, a system of equations was obtained. A difference representation of the boundary conditions was used to close this system. The obtained closed system of linear algebraic equations was solved numerically using a computer [48-50].

When implementing this method, an implicit four-point difference scheme was used. According to this scheme, it is necessary to take three points on the new time layer and one point from the old time layer. In this case, the temperature field is presented in implicit form. This scheme is used quite frequently because of its stability [48-50].

The solution area was presented as a set of nodes. A homogeneous difference grid was used. For each node, a system of linear algebraic equations was created as a result of replacement of the differential operators by their finite-difference analogues. On hundred nodes were used.

Further, the coefficients in front of the temperature field values were evaluated. The previously obtained three-point equation was transformed to a two-point form. The indices in these two-point equations were decreased by one.

These two-point equations were substituted into the obtained three-point equations. The coefficients $\alpha_{1}$ and $\beta_{1}$ were evaluated using the left boundary condition. Then, running coefficients $\alpha_{\mathrm{i}}$ and $\beta_{\mathrm{i}}$ were calculated for each node of the grid. Further, the right boundary condition was used to determine the temperature in the last grid node. As a result, for $\mathrm{N}$ nodes, the temperature at the boundary had the form $\mathrm{T}_{\mathrm{N}}(\mathrm{K})$. After that, a backward run was used to calculate the temperature distribution in the solution area [48-50].

The equation with the first accuracy order boundary conditions was used. Convective heat transfer at the boundary of the solution area was considered. An approximation on the area boundaries was evaluated in form [47]: 
On the left border $z=B_{0}$ :

$$
-\left.\lambda_{1} \frac{\partial T_{1}}{\partial z}\right|_{z=B_{0}}=\alpha\left(T_{f f}-T_{1}\right)
$$

The 4th kind boundary conditions were applied between leave layers. At the layer boundary $z=B_{1}, B_{2}$ (some $j$-th node).

On the right border, the influence of the forest fire temperature was taken into account by setting the third kind boundary condition. This boundary condition describes the convective heat transfer between the sample and the forest fire flame.

A general forest fire mathematical model was developed earlier, but it still has not been fully realized $[10,51,52]$. In [47], the main provisions of this model were used and a mathematical model of heat transfer was developed, taking into consideration the pyrolysis of dry organic matter. This model can be used as a software module in forest fire danger prediction systems, as pyrolysis is one of the most important stages before forest fuel ignition. However, to assess the environmental impact, it is necessary to improve this model and supplement it with a kinetic equation describing the formation of soot. In this work, the equation proposed in [10] was used. It should be clarified that this equation is valid only for the stage of pyrolysis of forest fuel. That is, the proposed mathematical model could be used to assess the production of soot particles during the pyrolysis of forest fuel [53].

List of assumptions

(1) One stage pyrolysis process is considered;

(2) Brutto reaction with known thermokinetic parameters is used;

(3) Arrhenius approach is used to describe pyrolysis process;

(4) Thermophysical properties depend on temperature using effective characteristics;

(5) The birch leaf has been considered as a three-layer plate;

(6) The first and the third layers of this plate have been described as dry organic matter;

(7) The second layer was a mixture of dry organic matter and water;

(8) Moisture evaporation is described by the kinetic approach;

(9) Water vapor instantaneously move to the area above the leaf;

(10) Soot particle volume fraction is proportional to the volume fraction of dry organic matter decomposed during pyrolysis with coefficient of dispersion $\alpha_{s}$.

(11) Temperature distribution is described by the unsteady heat conduction equation;

(12) Modeling has been carried out as part of a one-dimensional formulation to satisfy requirements of memory and software performance for practical purposes.

The geometry of the solution area is shown in Figure 1.

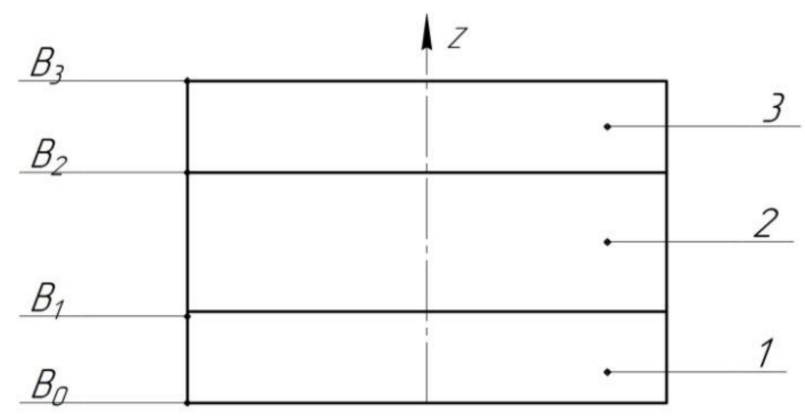

Figure 1. Geometry of the solution area (birch leaf): 1 is the dry organic matter layer; 2 is the layer representing a mixture of dry organic matter and water; 3 is the dry organic matter layer. Information from [54] was used to assign thicknesses to specific layers.

A scheme of the problem is shown in Figure 2. 


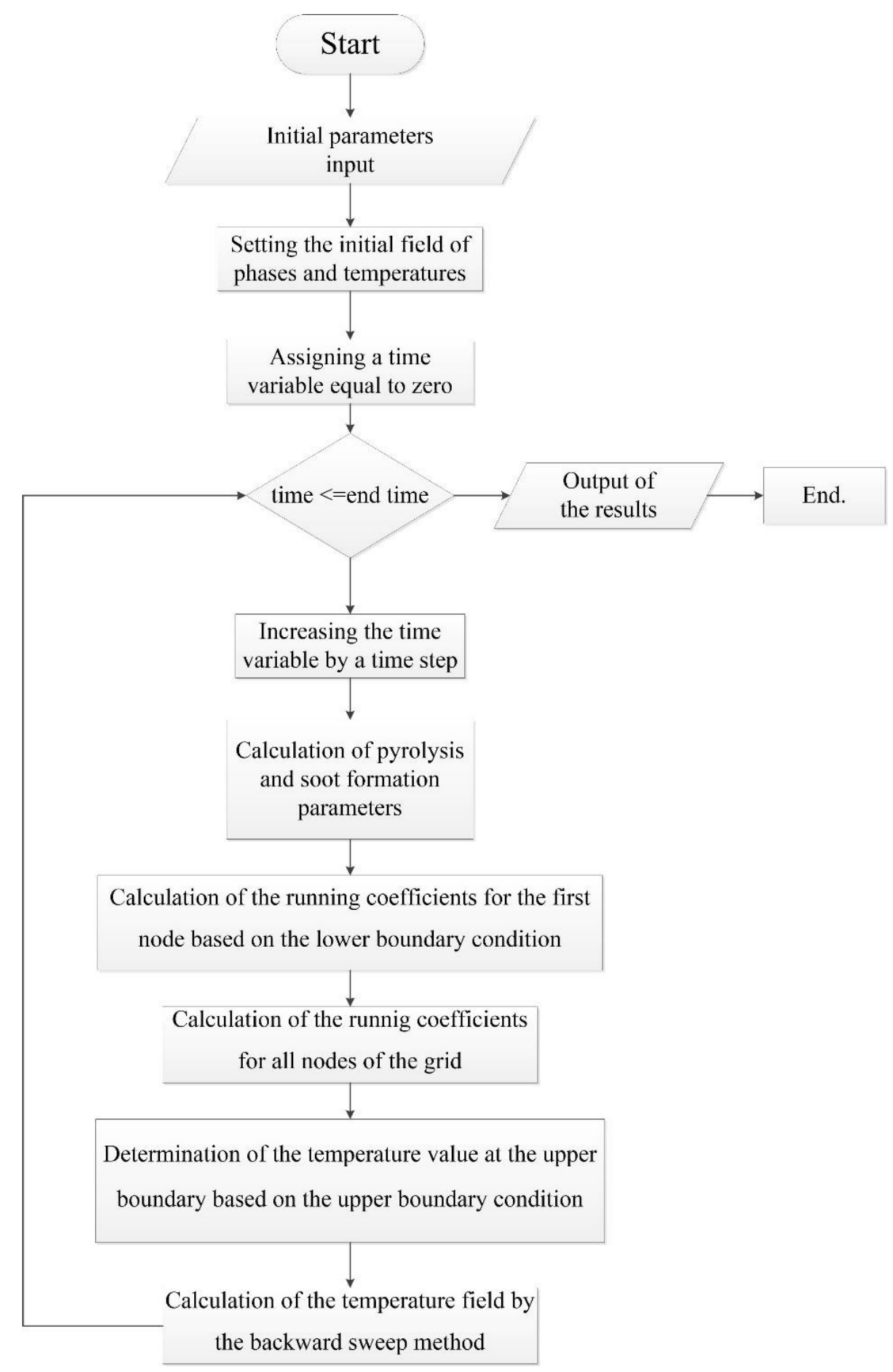

Figure 2. Scheme of the problem.

During numerical simulation, the one-dimensional heat equation and kinetic equation were solved:

$$
\begin{gathered}
\rho_{i} c_{i} \frac{\partial T_{i}}{\partial t}=\lambda_{i} \frac{\partial^{2} T_{i}}{\partial z^{2}}-q_{p} k \varphi_{1} \exp \left(-\frac{E}{R T_{i}}\right)-q_{e v W_{e v}} \\
\rho_{i} \frac{\partial \varphi_{1}}{\partial t}=-k \rho_{i} \varphi_{1} \exp \left(-\frac{E}{R T_{i}}\right), \\
\rho_{s} \frac{\partial \varphi_{2}}{\partial t}=\alpha_{s} k \rho_{s} \varphi_{1} \exp \left(-\frac{E}{R T_{i}}\right), \\
\rho_{3} \frac{\partial \varphi_{3}}{\partial t}=-w_{e v}
\end{gathered}
$$


where $w_{e v}$ is the evaporation rate, which is calculated by the formula:

$$
w_{e v}=\frac{A\left(P^{s}-P^{*}\right)}{\sqrt{\frac{2 \pi R T_{i}}{M}}}
$$

where $P^{s}$ is the saturated vapor pressure, $A$ is the accommodation coefficient, $R=8.31 \mathrm{~J} /(\mathrm{mol} \cdot \mathrm{K})$ is the universal gas constant, and $M$ is the molecular weight.

Equation (4) describes the pyrolysis process for dry organic matter within the Arrhenius model for brutto reaction. This reaction is characterized by thermokinetic parameters such as energy of activation $\mathrm{E}$ and pre-exponent $k$ with thermal effect $q_{p}$. This equation gives a quantitative assessment of the volume fraction for dry organic matter $\varphi_{1}$. Soot particle formation can be estimated using Equation (5). This equation describes the process of soot formation in terms of the proportional volume fraction for dry organic matter decomposed during pyrolysis to volume fraction of soot particles with coefficient $\alpha_{s}$. Both equations are ordinary differential equations that can be solved with the finite difference method.

The initial and boundary conditions were:

$$
\begin{gathered}
t=0 ; T_{i}=T_{i 0} \\
z=0 ;-\lambda_{1} \frac{\partial T_{1}}{\partial z}=\alpha\left(T_{1}-T_{f f}\right), \\
z=L_{z} ; \lambda_{3} \frac{\partial T_{3}}{\partial z}=\alpha\left(T_{3}-T_{f f}\right) \\
z=L_{z 1} ;-\lambda_{3} \frac{\partial T_{3}}{\partial z}=-\lambda_{2} \frac{\partial T_{2}}{\partial z}, T_{3}=T_{2} \\
z=L_{z 2} ;-\lambda_{2} \frac{\partial T_{2}}{\partial z}=-\lambda_{1} \frac{\partial T_{1}}{\partial z}, T_{2}=T_{1} \\
t=0 ; \varphi_{i}=\varphi_{i 0} \\
\sum_{i=1}^{4} \varphi_{i}=1
\end{gathered}
$$

where $\alpha$ is the heat transfer coefficient; $\alpha_{1}$ is the first left running coefficient in the first node; $\alpha_{j}{ }^{*}$ is the running coefficient in the border between the leaf layers; $\alpha_{s}$ is the dispersion coefficient; $\beta_{1}$ is the left running coefficient in the first node; $\beta_{j}{ }^{*}$ is the running coefficient in the border between leaf layers; $c$ is the specific heat; $\rho$ is the density; $\lambda$ is the thermal conductivity coefficient; $\varphi_{1}$ is the dry organic matter fraction; $\varphi_{2}$ is the soot particle fraction; $\varphi_{3}$ is the moisture fraction; $\varphi_{4}$ is the gas phase fraction; $E, k$, and $q_{p}$ are the activation energy, pre-exponent, and thermal effect of the forest fuel pyrolysis reaction, respectively; $R$ is the universal gas constant; $z$ is the spatial coordinate; $h$ is the spatial step; $i=1,2,3$ are the forest fuel layers; $N$ is the number of nodes; $Q(t, z)$ is the nonlinear part of the equation; $t$ is the time coordinate; $T_{f f}$ is the flame temperature; $T_{i}$ is the forest fuel temperature in the point of the i-th layer; $L_{z}$ is the overall thickness of the birch leaf; $L_{z 1}$ is the boundary between the second and third layers; and $L_{z 2}$ is the boundary between the second and first layers.

The following thermophysical and thermokinetic parameters were used [10]:

$$
\begin{gathered}
q_{p}=1000 \mathrm{~J} / \mathrm{kg}, \\
\mathrm{E} / \mathrm{R}=9400 \mathrm{~K}, \\
k=36,300 \mathrm{~s}^{-1}, \\
\alpha_{s}=0.05, \\
\rho_{\mathrm{s}}=300.0 \mathrm{~kg} / \mathrm{m}^{3},
\end{gathered}
$$

For dry organic matter

$$
\lambda=0.13 \mathrm{~W} /(\mathrm{m} \cdot \mathrm{K})
$$




$$
\begin{gathered}
\rho=290.0 \mathrm{~kg} / \mathrm{m}^{3}, \\
c=1450.0 \mathrm{~J} /(\mathrm{kg} \cdot \mathrm{K}),
\end{gathered}
$$

For water

$$
\begin{gathered}
\lambda=0.56 \mathrm{~W} /(\mathrm{m} \cdot \mathrm{K}), \\
\rho=1000.0 \mathrm{~kg} / \mathrm{m}^{3}, \\
c=4220.0 \mathrm{~J} /(\mathrm{kg} \cdot \mathrm{K}),
\end{gathered}
$$

In [55], a scenario modeling approach was developed for predicting forest fire danger. In this work, mathematical modeling of heat and mass transfer in a forest fuel element was carried out. The model presupposes accounting for the processes of dry organic matter pyrolysis and soot formation.

The development of this mathematical model was dictated by the need for information and computing systems for assessing, monitoring and predicting forest fire impacts on the population and the functioning of industrial and infrastructure facilities located in forested areas. The literature review revealed that at present, there are a number of works where the soot formation process during forest fires is described. However, the main drawback of all such mathematical models is the impossibility of their practical application on a national scale-in particular, in the Russian Federation. Table 1 shows the main input parameters that were mapped to different modeling scenarios. Even a simplified mathematical model requires a number of parameters that are not always possible to determine in practice due to extensive vegetation biodiversity and the inability to control all forest fire incidents.

\begin{tabular}{|c|c|c|c|c|c|c|c|c|c|}
\hline Scenario & $T_{f f}$ & $T_{0}$ & $\alpha_{s}$ & $t_{\text {end }}$ & $\alpha_{\mathbf{e}}$ & $\lambda$ & $\rho$ & $c$ & $\varphi_{30}$ \\
\hline Forest fire type & + & & & & + & & & & \\
\hline Season & & + & & & & & & & \\
\hline Forest fuel type & & & & & & + & + & + & \\
\hline Moisture content & & & & & & & & & + \\
\hline Smoke generation & & & + & & & & & & \\
\hline Duration & & & & + & & & & & \\
\hline
\end{tabular}
Therefore, in this work, we proposed using the scenario modeling approach, which has already been successfully applied in a number of works devoted to predicting forest fire danger, for example, [56,57].

Table 1. Correspondence of scenarios and various parameters of the model.

The proposed scenarios, first of all, take into account the forest fire type and the period of the fire danger season. In the Russian Federation, the ISDM-Rosleskhoz Information System for Remote Monitoring of Forest Fires is in operation [58]. This system uses, inter alia, probabilistic predictions of forest fire danger and remote sensing data on active forest fires. The system contains information on the characteristics of forest areas and information on detected forest fires. These data can be used to set the forest fire and forest fuel, respectively, and to compare them with specific values of thermophysical and thermokinetic characteristics for scenario modeling.

In this paper, four types of forest fires were considered, namely, low and high intensity surface forest fires, crown forest fires and firestorms [59-62]. There are differences between these types of forest fires: first of all, the forest fire front maximum temperature and propagation speed, and the group of forest fuels involved in combustion [10]. The front temperature was defined on the basis of the following scenarios: a low $(900 \mathrm{~K})$ and high $(1000 \mathrm{~K})$ intensity surface forest fire, a crown forest fire (1100 K) and a fire storm (1200 K). The speed of the incident flow during the forest fire front movement could be indirectly taken into account when specifying the heat transfer coefficient in the boundary conditions. The type of forest fuel was, accordingly, taken into account when setting the thermophysical 
and thermokinetic properties. In this work, heat and mass transfer in an element of a typical forest fuel of deciduous species (birch leaf) was investigated. The choice of this particular type of forest fuel for research should be explained separately. In the Russian Federation, as a rule, coniferous and mixed forest stands pose a great fire danger [63].

However, it was previously established in experiments on the ignition of a forest fuel by a source of elevated temperature that a birch leaf has an ignition temperature lower than that of conifer needles [64]. That is, in mixed stands there is a risk of a forest fire from a local fire caused by birch leaf ignition. In addition, it is necessary to understand what contribution to the ecological consequences of forest fires is made by foliage along with needles during forest fires in mixed stands.

In the Russian Federation, the fire season lasts, on average, from April to October. Therefore, the entire fire danger season can be divided into three periods: spring, summer and autumn. For scenario modeling, the average ambient temperatures were used for each of the periods across the territory of the Republic of Buryatia (Russian Federation) [65].

In recent years, significant efforts have been made to develop methods for forest fire danger monitoring, prediction and assessment, for example, in the Baikal basin [66-68]. Currently, a project is being implemented to develop methods for monitoring forest fire dangers caused by transport infrastructure, namely, railways. Railways are one of the sources of fire danger in forested areas [69,70]. However, forest fires affect railway operations as well. Soot and smoke particles can cause illness and death for railway employees and train passengers. In addition, scenarios of minimum, medium and maximum soot formation were considered. These scenarios were taken into account when defining the dispersion coefficient [10]. Additionally, calculations were carried out to take into account the various values of the moisture volume fraction in the forest fuel structure and the duration of exposure to elevated temperatures from the forest fire front.

In this research, a scenario was a set of parameters. Table 1 shows data accounting for various parameters of the mathematical model in various scenarios during modeling.

During mathematical modeling, four scenario groups were used. The main input parameters of each group are listed below (Table 2).

Table 2. Main input parameters for different scenarios.

\begin{tabular}{|c|c|c|c|c|}
\hline Fire Type & $\begin{array}{c}\text { Low-Intensity } \\
\text { Surface Forest } \\
\text { Fire }(900 \mathrm{~K})\end{array}$ & $\begin{array}{l}\text { High-Intensity } \\
\text { Forest Fire } \\
\text { (1000 K) }\end{array}$ & $\begin{array}{l}\text { Crown Forest } \\
\text { Fire }(1100 \mathrm{~K})\end{array}$ & $\begin{array}{c}\text { Fire Storm } \\
(1200 \mathrm{~K})\end{array}$ \\
\hline Season: & \multicolumn{4}{|c|}{ spring $\left(\right.$ April $\left.+6^{\circ} \mathrm{C}\right)$, summer $\left(\mathrm{July}+20^{\circ} \mathrm{C}\right)$, autumn (October $\left.0{ }^{\circ} \mathrm{C}\right)$} \\
\hline $\begin{array}{l}\text { Duration of forest } \\
\text { fire front impact: }\end{array}$ & \multicolumn{4}{|c|}{$2,3,5 \mathrm{~s}$} \\
\hline Soot generation: & \multicolumn{4}{|c|}{$\alpha_{s}=0.01 ; 0.03 ; 0.05$} \\
\hline $\begin{array}{l}\text { Volume fraction of } \\
\text { moisture: }\end{array}$ & \multicolumn{4}{|c|}{$0.2 ; 0.3 ; 0.4$} \\
\hline $\begin{array}{l}\text { Volume fraction of } \\
\text { dry organic } \\
\text { matter: }\end{array}$ & \multicolumn{4}{|c|}{$0.8 ; 0.7 ; 0.6$} \\
\hline
\end{tabular}

\section{Results and Discussion}

Further, the specific results of scenario group I were considered, that is, a low-intensity surface forest fire. Figures 3-5 show temperature distributions over the thickness of a birch leaf under typical conditions of the summer season for different times of exposure to elevated temperatures from the front of a low-intensity forest fire 


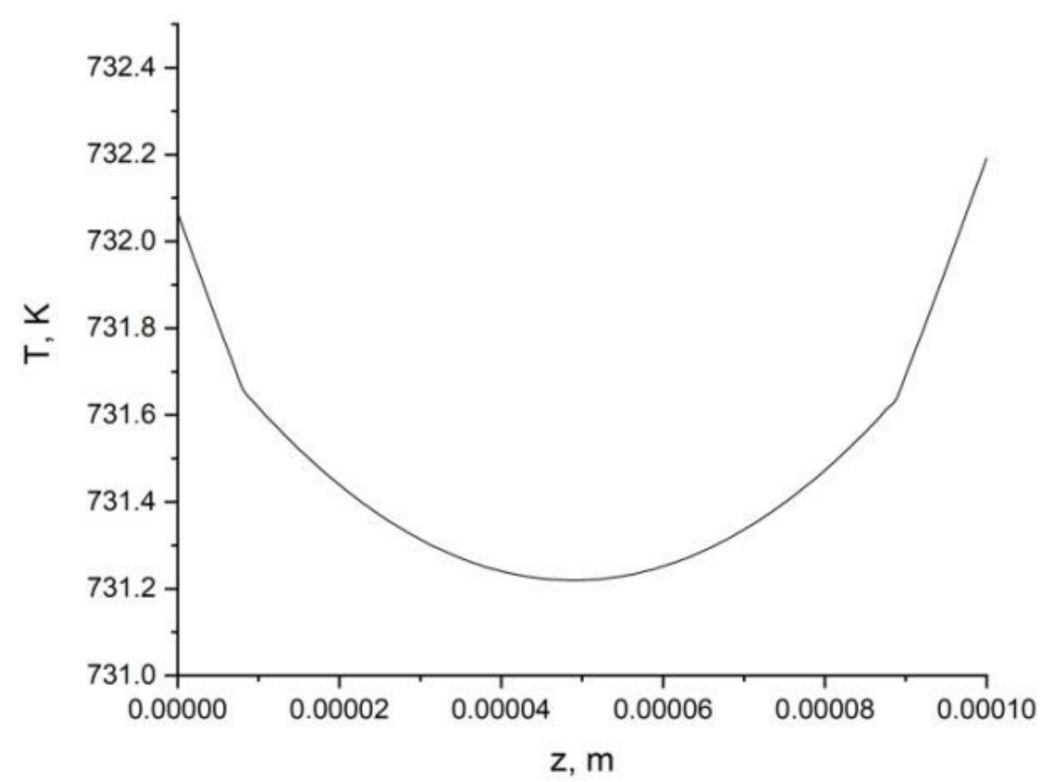

Figure 3. Temperature distribution over the thickness of a birch leaf under the influence of a lowintensity surface forest fire at time $\mathrm{t}=2 \mathrm{~s}$ (summer, July, $+20^{\circ} \mathrm{C}, \varphi_{30}=0.4$ ).

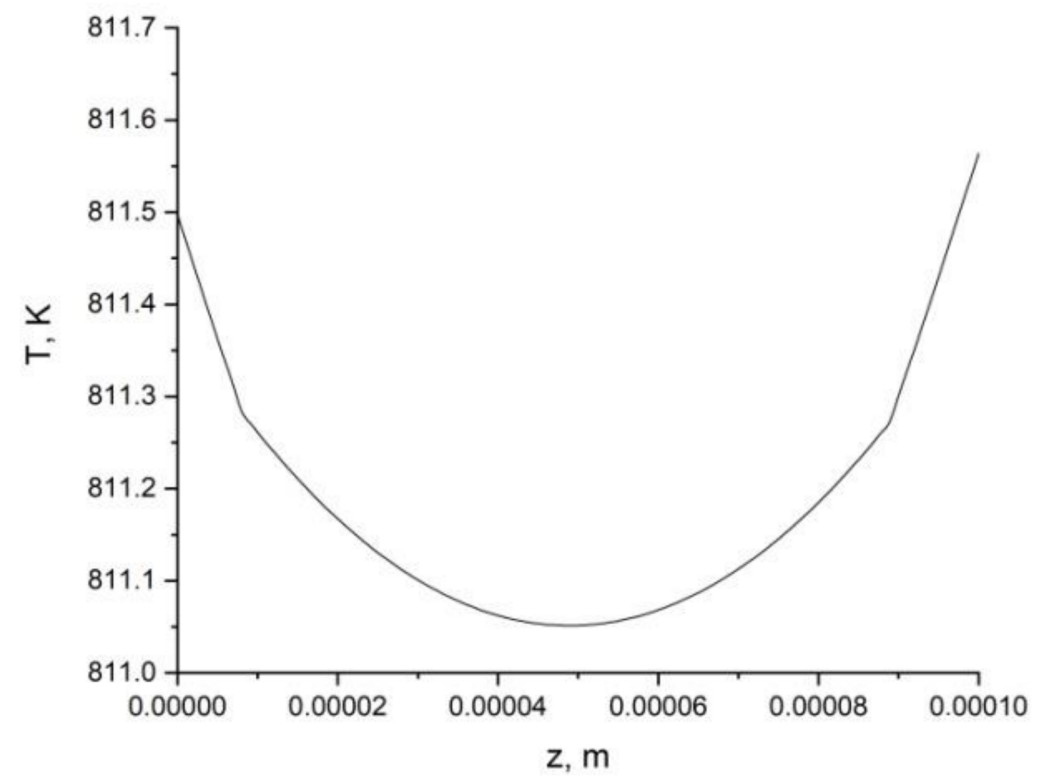

Figure 4. Temperature distribution over the thickness of a birch leaf under the influence of a lowintensity surface forest fire at time $\mathrm{t}=3 \mathrm{~s}$ (summer, July, $+20^{\circ} \mathrm{C}, \varphi_{30}=0.4$ ).

The analysis of temperature distributions presented in Figures 3-5 shows that the main effect of a forest fire is due to the duration of exposure to a forest fuel element. There was a noticeable difference in the temperature distribution over the thickness of the birch leaf at exposure times of 2, 3 and $5 \mathrm{~s}$. However, the temperature gradients along the leaf thickness were small because the leaf plate was quite thin and had time to warm up through almost the entire thickness. The ambient temperature had no significant effect on the temperature distribution in the birch leaf structure. For example, the difference in the maximum leaf temperatures was 1-6 K, depending on the period of the fire danger season. Moreover, the shorter the duration of exposure to a forest fire, the greater the difference in the maximum leaf temperatures. 


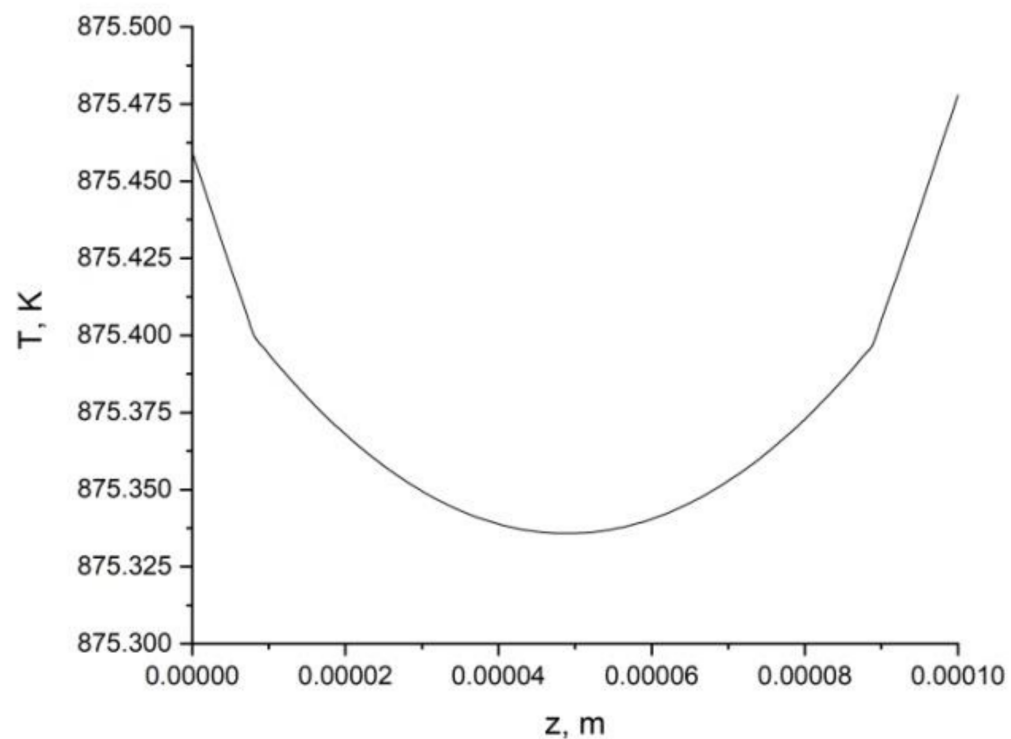

Figure 5. Distribution of temperature over the thickness of a birch leaf under the influence of a low-intensity surface forest fire at time $\mathrm{t}=5 \mathrm{~s}$ (summer, July, $+20^{\circ} \mathrm{C}, \varphi_{30}=0.4$ ).

Figures 6-8 show the curves of the volume fractions of various phases depending on the duration of exposure to a low-intensity surface forest fire (summer, in the middle of the 2nd layer).

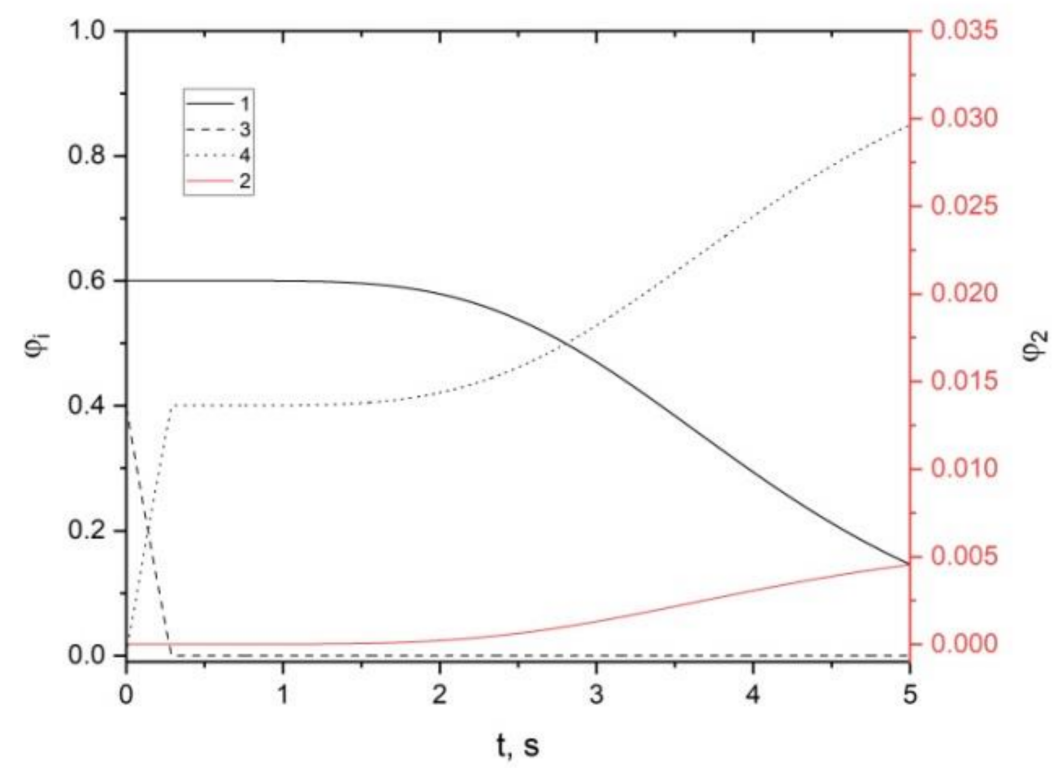

Figure 6. Distribution of volume fractions of phases under the influence of a low-intensity surface forest fire depending on time (summer, July, $+20{ }^{\circ} \mathrm{C}, \varphi_{30}=0.4, \alpha_{s}=0.01$ ): 1 -dry organic matter, 2-soot particles, 3-moisture, 4-gas. 


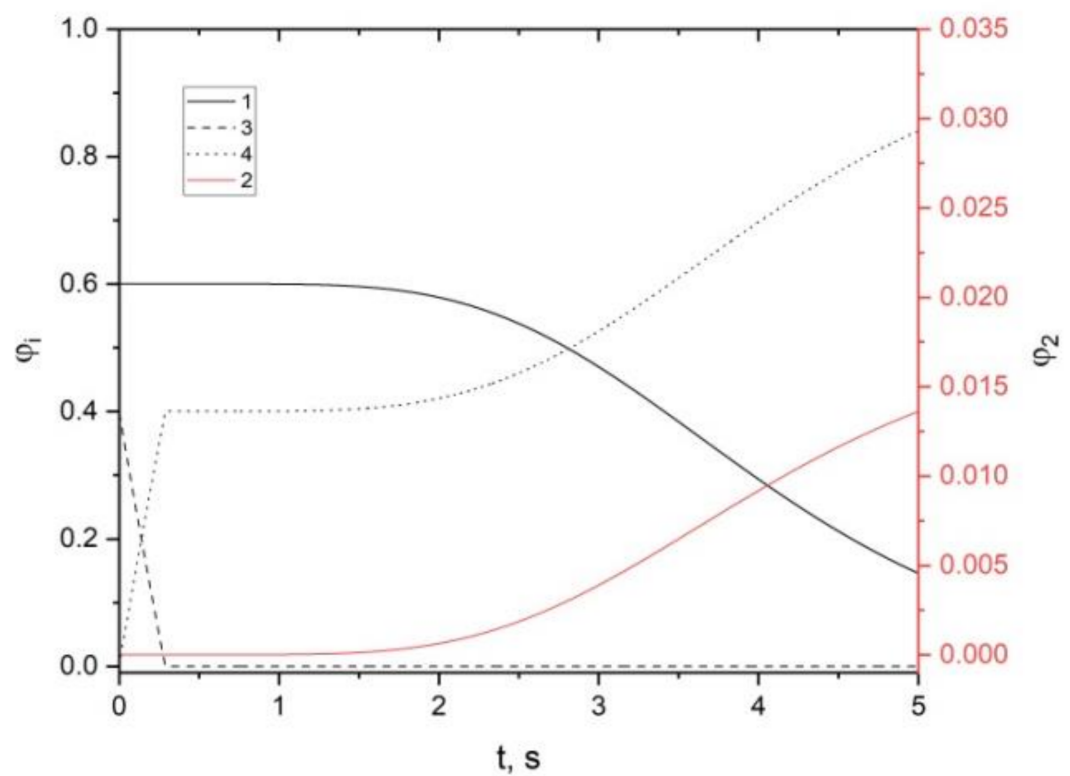

Figure 7. Distribution of volume fractions of phases under the influence of a low-intensity surface forest fire depending on time (summer, July, $+20{ }^{\circ} \mathrm{C}, \varphi_{30}=0.4, \alpha_{S}=0.03$ ): 1 -dry organic matter, 2-soot particles, 3-moisture, 4-gas.

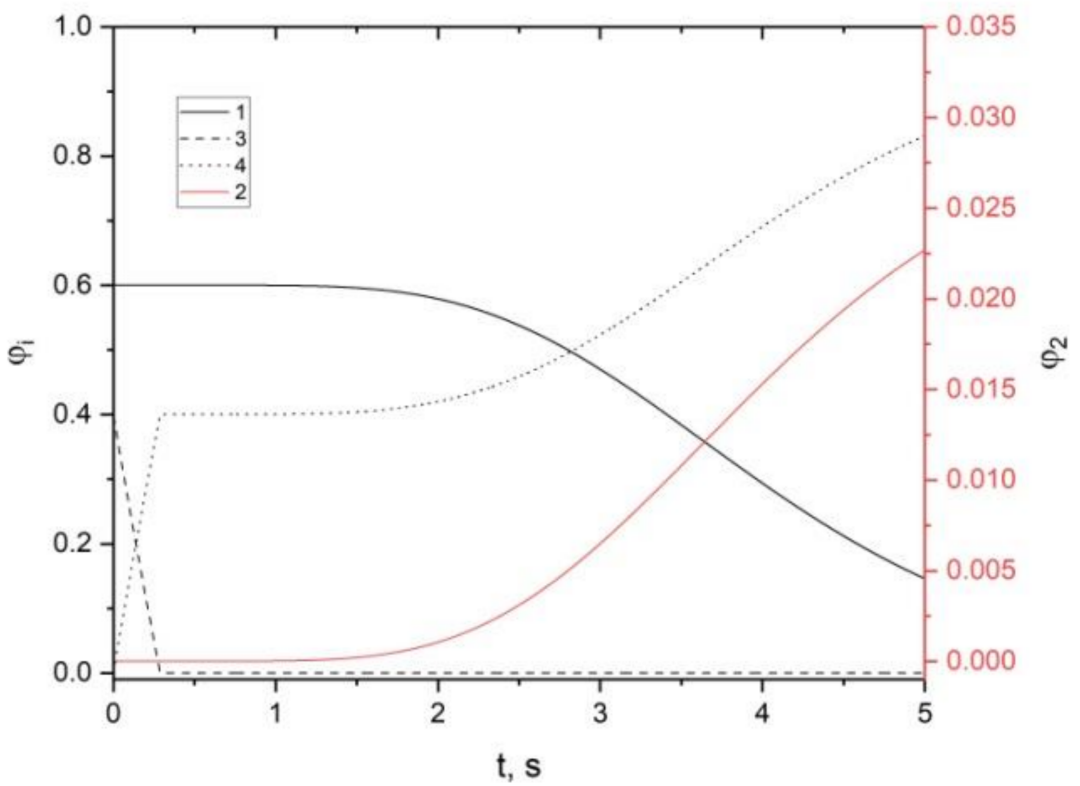

Figure 8. Distribution of volume fractions of phases under the influence of a low-intensity surface forest fire depending on time (summer, July, $+20^{\circ} \mathrm{C}, \varphi_{30}=0.4, \alpha_{s}=0.05$ ): 1 -dry organic matter, 2-soot particles, 3-moisture, 4-gas.

Analysis of the results presented in Figures 6-8 led to the following conclusions. First, the dispersion coefficient has the greatest influence on soot formation. The higher the value of this coefficient, the higher the value of the volume fraction of the formed soot particles. For example, the values of the volume fraction of soot particles reached 0.005 for the minimum scenario and 0.023 for the maximum scenario of soot formation. Accordingly, in summer and autumn, these values were 0.005 and 0.03 as well. This result is due to the dependence of the soot formation kinetics on the thermal decomposition kinetics in the model. According to the kinetic scheme, the dry organic matter pyrolysis is determined by the temperature that is reached in the forest fuel element. As mentioned earlier, these 
differences are minimal for fire season periods. It should also be noted that the gradients of the soot particle volume fraction are significantly higher in the maximum soot formation scenario. Moreover, a noticeable formation occurs when the exposure time is more than $2 \mathrm{~s}$.

Figures 9-11 show the resulting distributions of volume fractions of phases by the end of the effect of elevated temperature from the front of a low-intensity surface forest fire. The scenario of maximum soot production was considered.

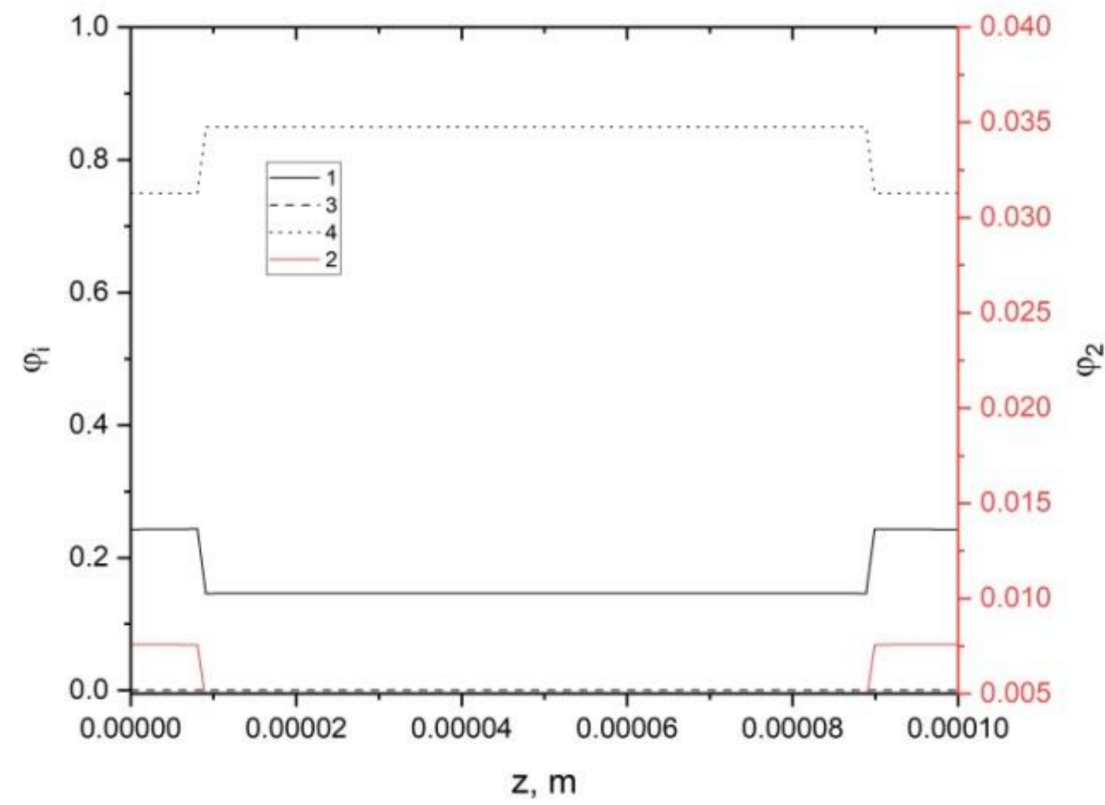

Figure 9. Distribution of volume fractions of phases under the influence of a low-intensity surface forest fire depending on the thickness of the leaf at time $\mathrm{t}=5 \mathrm{~s}$ (spring, April, $+6{ }^{\circ} \mathrm{C}, \varphi_{30}=0.4$, $\left.\alpha_{s}=0.05\right): 1$-dry organic matter, 2—soot particles, 3-moisture, 4-gas.

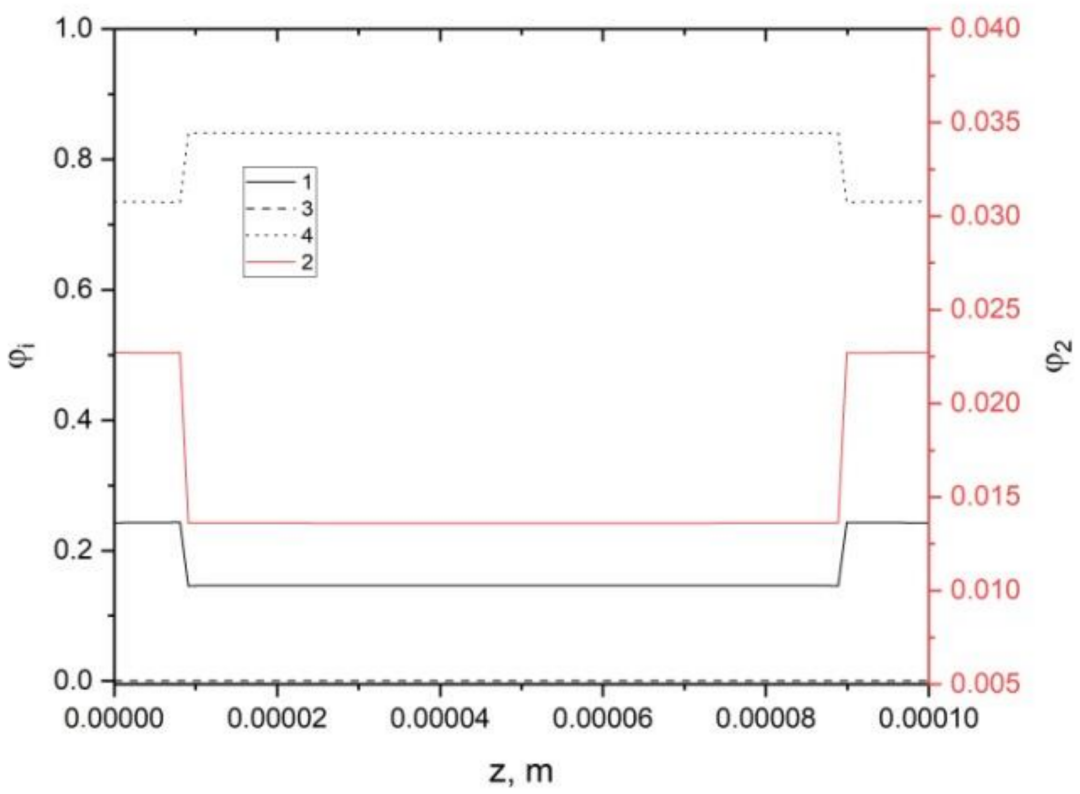

Figure 10. Distribution of volume fractions of phases under the influence of a low-intensity surface forest fire depending on the thickness of the leaf at time $\mathrm{t}=5 \mathrm{~s}$ (summer, July, $+20^{\circ} \mathrm{C}, \varphi_{30}=0.4$, $\left.\alpha_{s}=0.05\right)$ : 1 -dry organic matter, 2-soot particles, 3-moisture, 4-gas. 


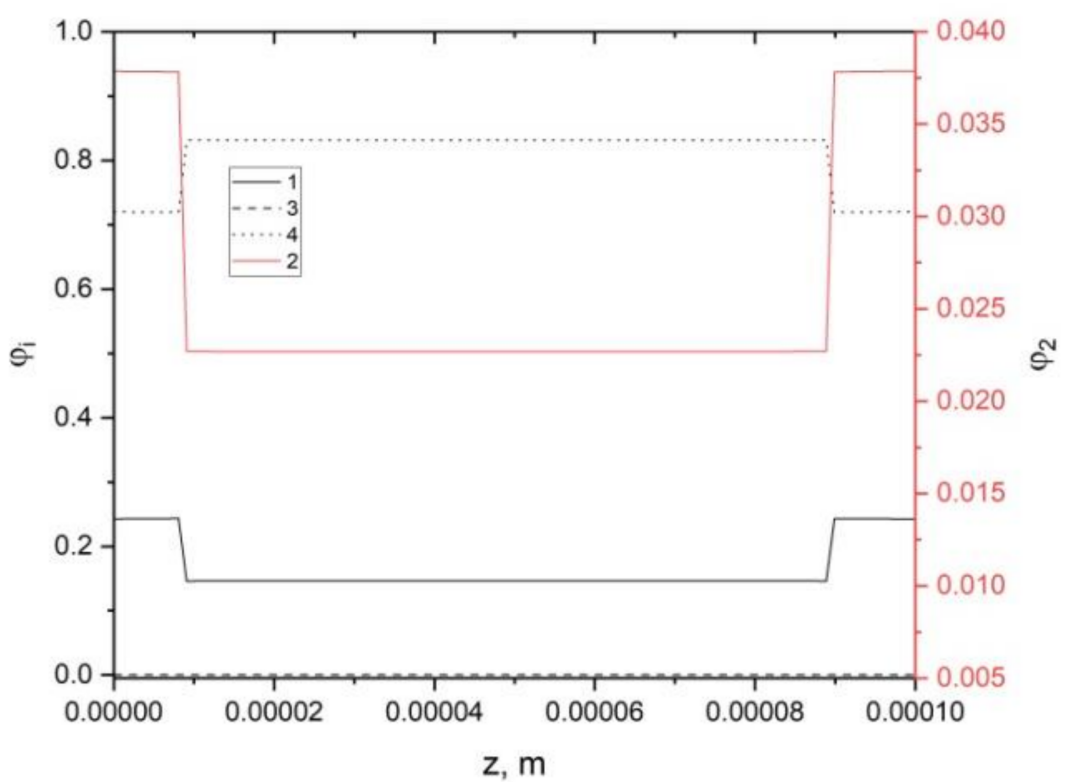

Figure 11. Distribution of volume fractions of phases under the influence of a low-intensity surface forest fire depending on the thickness of the leaf at time $\mathrm{t}=5 \mathrm{~s}$ (autumn, October, $+0{ }^{\circ} \mathrm{C}, \varphi_{30}=0.4$, $\left.\alpha_{s}=0.05\right)$ : 1 -dry organic matter, 2-soot particles, 3-moisture, 4-gas.

Analysis of the data presented in Figures 9-11 showed that the volume fraction of soot particles in the limit can reach values close to 3\%. Moreover, the maximum amount of soot particles forms at the leaf edges, where the temperature values are also at a maximum, which causes a more intense thermal decomposition process.

Figures 12 and 13 show the curves of volume fractions of phases depending on the time of exposure to a low-intensity surface forest fire, respectively, for $\varphi_{30}=0.3$ and $\varphi_{30}=0.2$ (in the middle of the 2nd layer).

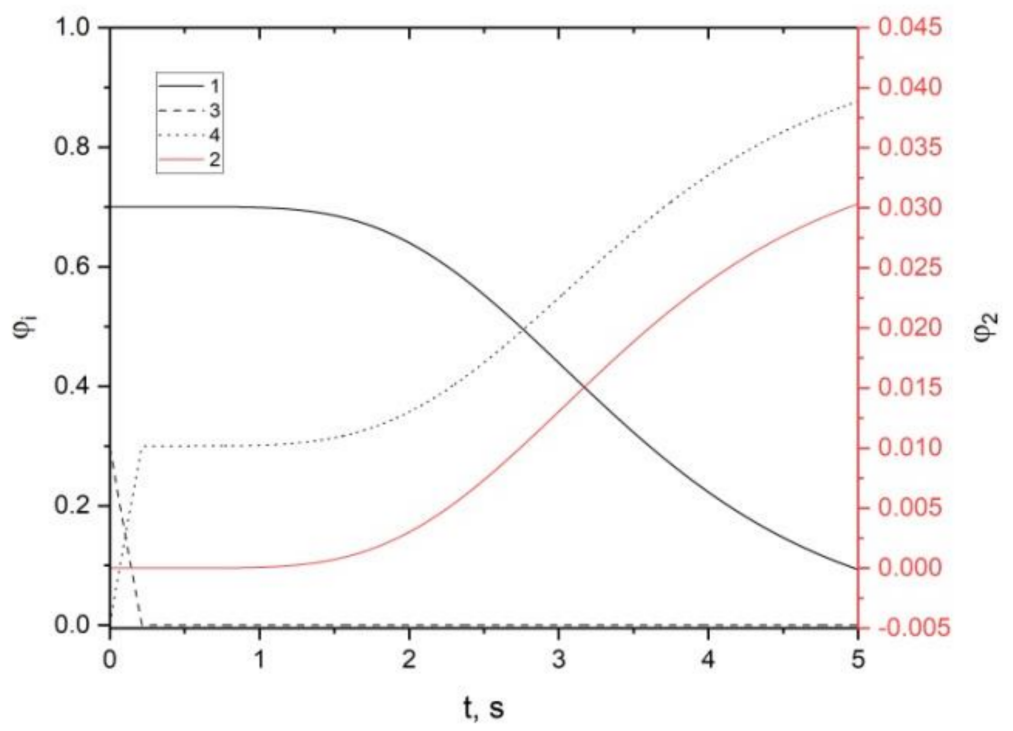

Figure 12. Distribution of volume fractions of phases under the influence of a low-intensity surface forest fire depending on time (summer, July, $+20{ }^{\circ} \mathrm{C}, \varphi_{30}=0.3, \alpha_{s}=0.05$ ): 1 -dry organic matter, 2-soot particles, 3-moisture, 4-gas. 


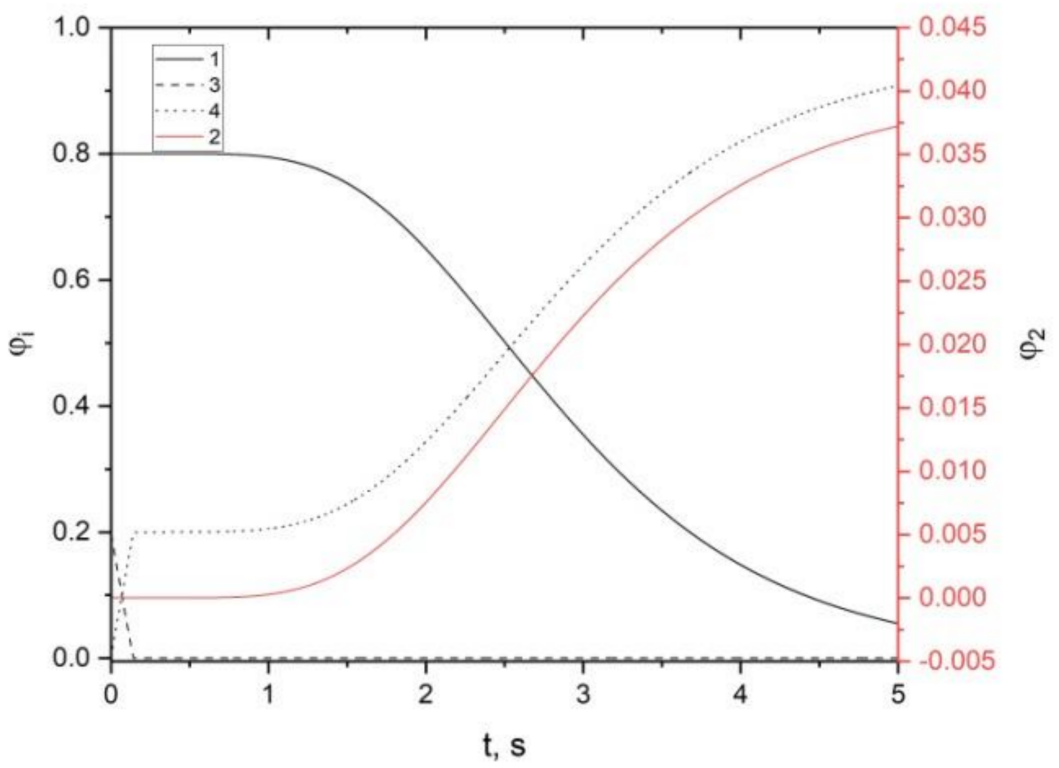

Figure 13. Distribution of volume fractions of phases under the influence of a low-intensity surface forest fire depending on time (summer, July, $+20{ }^{\circ} \mathrm{C}, \varphi_{30}=0.2, \alpha_{s}=0.05$ ): 1 -dry organic matter, 2-soot particles, 3-moisture, 4-gas.

Figures 14 and 15 show, respectively, the resulting distributions of the volume fractions of phases for these values $\varphi_{30}=0.3$ and $\varphi_{30}=0.2$. Both options were considered under conditions of maximum soot production.

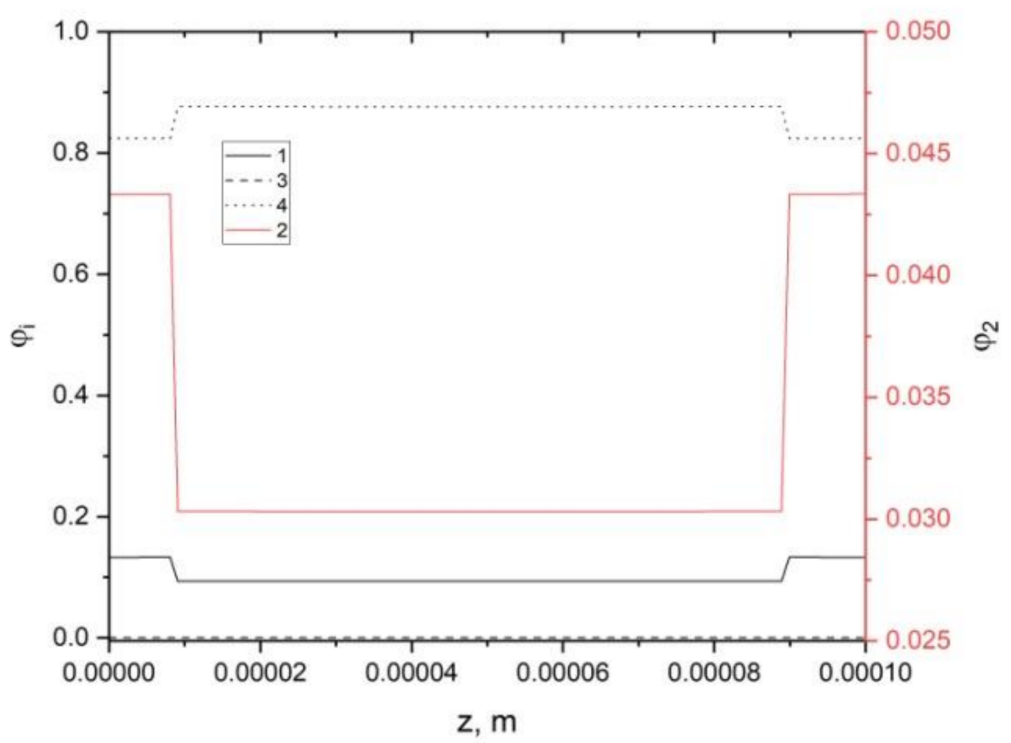

Figure 14. Distribution of volume fractions of phases under the influence of a low-intensity surface forest fire depending on the thickness of the leaf at time $t=5 \mathrm{~s}$ (summer, July, $+20{ }^{\circ} \mathrm{C}, \varphi_{30}=0.3$, $\left.\alpha_{s}=0.05\right)$ : 1 -dry organic matter, 2-soot particles, 3-moisture, 4-gas. 


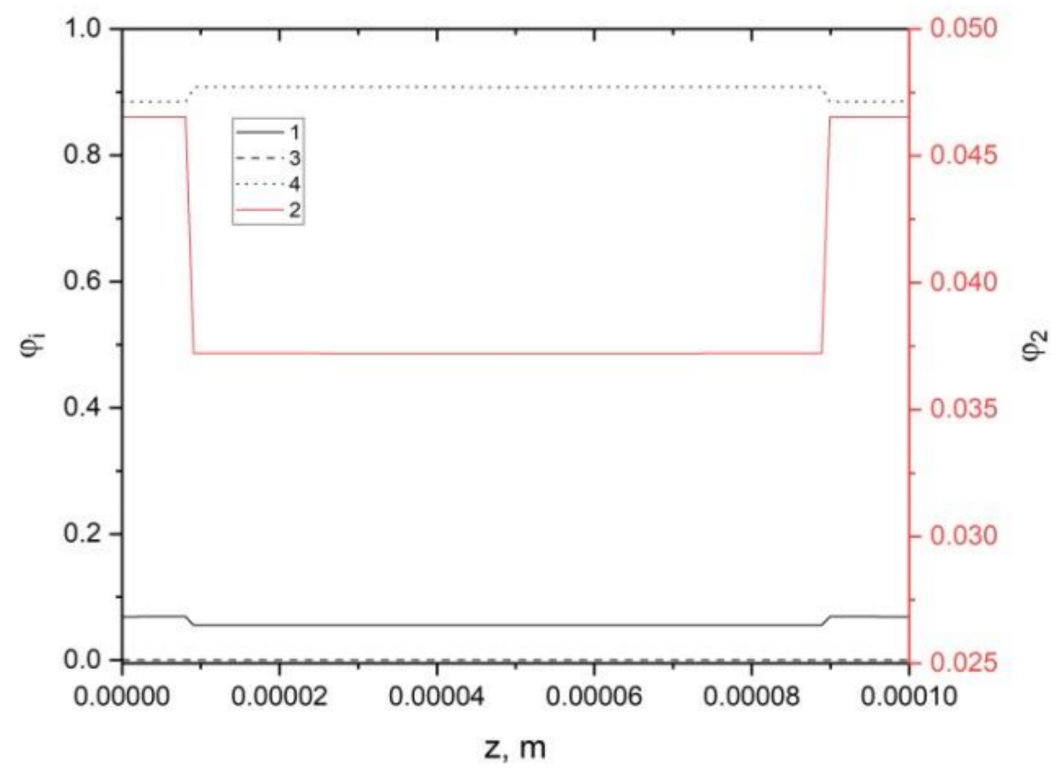

Figure 15. Distribution of volume fractions of phases under the influence of a low-intensity surface forest fire depending on the thickness of the leaf at time $\mathrm{t}=5 \mathrm{~s}$ (summer, July, $+20^{\circ} \mathrm{C}, \varphi_{30}=0.2$, $\left.\alpha_{s}=0.05\right)$ : 1 -dry organic matter, 2-soot particles, 3-moisture, 4-gas.

In addition, calculations of soot formation were carried out for forest fuels with various levels of moisture content. The values of the moisture volume fraction were varied in the range from 0.2 to 0.4 . Analysis of the results presented in Figures 12-15 showed that a decrease in the moisture volume fraction leads to increased soot particle formation. This difference in absolute values is of the order of 0.01 , that is, there is an increase in soot particles by about one-third from a forest fuel with minimum moisture content.

Further, specific results were considered for scenario group II, that is, a high-intensity surface forest fire. Analysis showed that when exposed to increased temperature from the front of a high-intensity surface forest fire, the same patterns that are characteristic of a low-intensity surface forest fire are observed. The differences in the absolute values for the birch leaf temperature at different ambient temperatures are comparable to those observed for the scenario of a low-intensity surface forest fire.

Analysis shows that the same patterns of soot particle formation observed for a lowintensity surface forest fire also occur when exposed to a high-intensity surface forest fire. However, the maximum values of the soot particle volume fraction already reach 0.006 and 0.03 , respectively, in the minimum and maximum soot formation scenarios. The gradients of the soot particle volume fractions are higher and the process itself begins at an exposure time of $1.5 \mathrm{~s}$. The resulting values of the volume fraction are also higher in the scenario of a surface forest fire of high intensity. The influence of forest fuel moisture content was also studied. The same patterns were obtained as for the scenario of a low intensity surface forest fire. Only the values of the soot particle volume fraction are slightly higher for the scenario of the impact of a high-intensity surface forest fire.

Further, the specific results for scenario group III, that is, the impact of a crown forest fire, was considered. Analysis showed that the same qualitative regularities were found as for the previously considered surface forest fires. However, the absolute temperature values in the birch leaf structure were higher. As a result, the distribution of the soot particle volume fraction changed somewhat depending on the exposure time to a crown forest fire. The maximum values of the soot particle volume fraction for the minimum and maximum soot formation scenarios were 0.006 and 0.03 , respectively. Moreover, the soot formation process began approximately from the moment of time equal to $1 \mathrm{~s}$. The gradient of the volume fraction is was larger than in the previously considered scenarios of surface forest fires. At an exposure time of approximately $3 \mathrm{~s}$, the values for the soot particle volume 
fraction reach an asymptote. It should be noted here that at these temperatures, flame combustion of gaseous pyrolysis products readily occurs, but the resulting soot formation cannot be taken into account within the framework of the proposed mathematical model.

The resulting soot particle volume fraction distributions were similar to those from forest fires of other types. Moreover, maximum soot formation occurs at the leaf edges. Analysis of the influence of initial moisture content values also showed that the higher the moisture content, the fewer soot particles formed.

Following are specific results for scenario group IV, that is, for a firestorm. Analysis of the results showed an analogous temperature distribution in the birch leaf structure, taking into account the growth of its maximum value under the fire storm influence. Analysis revealed the same qualitative patterns as for the previously considered types of forest fires. Quantitative analysis showed that the soot particle volume fractions in the limit correspond to the values obtained for a crown forest fire. However, the gradients of their change over time were higher and the values of the volume fraction reached an asymptote over a shorter period. This is due to the fact that higher temperatures are reached faster in the forest fuel structure and the thermal decomposition process is more intensive. As a result, there were large gradients in the soot particle volume fraction that were intensely formed during the forest fuel pyrolysis. The resulting distribution of the soot particle volume fraction corresponded to the scenario of a crown fire. The results of the analysis of the influence of initial moisture content were analogous with the results typical for a crown forest fire. That is, the process of soot formation during a firestorm corresponds to that of a crown forest fire, but it occurs in a more intensive way and in a shorter period of time.

Generalizing remarks should be made regarding the obtained results. As shown by a qualitative analysis of the dependencies, the temperature distributions in the birch leaf structure were similar for all forest fire types and differed only in their absolute values. More intense heating occurs at the leaf surface. As a consequence, thermal decomposition and subsequent soot formation are more intense there. The influence of the ambient temperature is minimal in this model and is quantitatively expressed as a difference of several degrees for different periods of the fire season. In principle, for practical purposes, you can use the average temperature values typical for the entire fire season. This will significantly reduce the number of scenarios required to simulate different conditions of soot formation in predicting, assessing and monitoring forest fires in a studied forest area. The most noticeable quantitative differences were characteristic for different degrees of dispersion. The obtained results showed that the start of moisture evaporation is highly intensive in the first second of influence from the forest fire process. After one half of that first second, the value of moisture content is close to zero. This moisture evaporation behavior is caused by a model suggesting that water vapors are instantaneously removed from the forest fuel element. Thus, analysis of the simulation results showed that a sufficiently large number of soot particles are formed during the thermal decomposition of dry organic matter, and this contribution should be taken into account when assessing soot particle emissions in order to predict, monitor and assess forest fire danger [71-73].

As mentioned earlier, the main advantage of the developed mathematical model lies in the possibility of its application in practice for assessing, monitoring, and predicting the formation of soot particles during forest fires. On up-to-date computers (CPU Intel i5 $3 \mathrm{GHz}, 16 \mathrm{~GB}$ RAM), the calculation time using the developed mathematical model is less than $1 \mathrm{~s}$ for one variant. The mathematical model implementation was performed in the high-level programming language Delphi in the RAD Studio software [74]. In the future, it will be possible to integrate the developed model with geo-information systems [75-77] to visualize the predicted values of the volume fraction of soot particles formed during active forest fires. ArcGIS [78] and QGIS [79] can be used as host systems. Moreover, when using the developed mathematical model for the assessment, prediction and monitoring of forest fires [80] within a forest or administrative region, single-processor computers and a sequential programming paradigms are sufficient [81]. 
When organizing monitoring, assessing and predicting forest fire danger and environmental consequences on a national scale, for example, in the Russian Federation, it will be possible to further develop a parallel program in the SPMD computation model [82]. In this case, the multiprocessor computing systems at a number of universities can be used, for example $[83,84]$.

\section{Conclusions}

This article proposed a mathematical model of heat and mass transfer processes, taking into account the thermal decomposition of dry organic matter and soot particle formation. The paper used a scenario modeling approach that included information about the forest fire type, the period of the fire danger season, the forest fuel properties, the degree of dispersion of the forest fuel and the initial moisture content of the forest fuel element. The paper considered four scenario groups: low and high intensity surface forest fires, crown forest fires and firestorms.

It was revealed that the main influence on the soot formation process is exerted by the degree of dispersion of forest fuel and the forest fire type. However, it was established that the qualitative characteristics of the soot formation process are similar for all scenarios. Further research could be conducted to account for aerosol formation during the interaction of water vapor with soot particles.

The proposed mathematical model can be applied in practice in order to assess, monitor and predict the environmental consequences of forest fires, including in the vicinity of railway infrastructure. In addition, this mathematical model can be used to assess the contribution of soot particle formation during the thermal decomposition of dry organic matter in the forest fuel structure. Software implementations can be used in conjunction with geo-information systems to visualize input and output information in the assessment, monitoring and prediction of forest fires and their environmental consequences.

As for research that is in the interest of the Russian Railways, the use of the developed mathematical model in practice will make it possible to assess or predict the formation of soot particles from forest fires in the vicinity of railway infrastructure. It is very important to be able to predict possible emissions from such forest fires, because trains traveling on railroads lack maneuverability. Exposure to soot particles could be tragic if the particles are inhaled by railroad employees or passengers.

Author Contributions: Conceptualization, N.B.; methodology, N.B.; software, N.B. and V.K.; validation, N.B. and V.K.; formal analysis, N.B.; investigation, N.B. and V.K.; resources, N.B. and V.K.; data curation, V.K.; writing—original draft preparation, N.B. and V.K.; writing—review and editing, N.B..; visualization, V.K.; supervision, N.B.; project administration, N.B.; funding acquisition, N.B. Both authors have read and agreed to the published version of the manuscript.

Funding: The reported study was funded by RFBR, Sirius University of Science and Technology, JSC Russian Railways and Educational Fund "Talent and success", project number 20-31-51001.

Institutional Review Board Statement: Not applicable.

Informed Consent Statement: Not applicable.

Data Availability Statement: Data available on request due to restrictions of institution.

Conflicts of Interest: The authors declare no conflict of interest.

\section{References}

1. Baranovskiy, N.V.; Kuznetsov, G.V. Forest Fire Occurrences and Ecological Impact Prediction: Monograph; Publishing House of the Siberian Branch of the Russian Academy of Science: Novosibirsk, Russia, 2017. [CrossRef]

2. Punsompong, P.; Pani, S.K.; Wang, S.-H.; Bich Pham, T.T. Assessment of forest fuel-burning types and transport over Thailand and the associated health risks. Atmos. Environ. 2021, 247, 118176. [CrossRef]

3. Castagna, J.; Senatore, A.; Bencardino, M.; D'Amore, F.; Sprovieri, F.; Pirrone, N.; Mendicino, G. Multiscale assessment of the impact on air quality of an intense wildfire season in southern Italy. Sci. Total Environ. 2021, 761, 143271. [CrossRef] 
4. Adam, M.G.; Tran, P.T.M.; Bolan, N.; Balasubramanian, R. Forest fuel burning-derived airborne particulate matter in Southeast Asia: A critical review. J. Hazard. Mater. 2021, 407, 124760. [CrossRef] [PubMed]

5. Yoshizue, M.; Taketani, F.; Adachi, K.; Iwamoto, Y.; Tohjima, Y.; Mori, T.; Miura, K. Detection of aerosol particles from siberian forest fuel burning over the western north pacific. Atmosphere 2020, 11, 1175. [CrossRef]

6. Ryan, R.G.; Silver, J.D.; Schofield, R. Air quality and health impact of 2019-20 Black Summer megafires and COVID-19 lockdown in Melbourne and Sydney, Australia. Environ. Pollut. 2021, 274, 116498. [CrossRef] [PubMed]

7. Augusto, S.; Ratola, N.; Tarín-Carrasco, P.; Jiménez-Guerrero, P.; Turco, M.; Schuhmacher, M.; Costa, S.; Teixeira, J.P.; Costa, C. Population exposure to particulate-matter and related mortality due to the Portuguese wildfires in October 2017 driven by storm Ophelia. Environ. Int. 2020, 144, 106056. [CrossRef]

8. Invally, M.; Kaur, G.; Kaur, G.; Bhullar, S.K.; Buttar, H.S. Health care burden of cardiorespiratory diseases caused by particulate matter and chemical air pollutants. World Heart J. 2017, 9, 303-317.

9. Borchers-Arriagada, N.; Palmer, A.J.; Bowman, D.M.J.S.; Williamson, G.J.; Johnston, F.H. Health impacts of ambient forest fuel smoke in Tasmania, Australia. Int. J. Environ. Res. Public Health 2020, 17, 3264. [CrossRef] [PubMed]

10. Grishin, A.M. Mathematical Modeling of Forest Fire and New Methods of Fighting Them; Publishing House of the Tomsk State University: Tomsk, Russia, 1997; p. 390.

11. Josephson, A.J.; Castaño, D.; Koo, E.; Linn, R.R. Zonal-Based Emission Source Term Model for Predicting Particulate Emission Factors in Wildfire Simulations. Fire Technol. 2021, 57, 943-971. [CrossRef]

12. Sharma, A.; Pareek, V.; Zhang, D. Forest fuel pyrolysis-A review of modelling, process parameters and catalytic studies. Renew. Sustain. Energy Rev. 2015, 50, 1081-1096. [CrossRef]

13. Wang, S.; Dai, G.; Yang, H.; Luo, Z. Lignocellulosic forest fuel pyrolysis mechanism: A state-of-the-art review. Prog. Energy Combust. Sci. 2017, 62, 33-86. [CrossRef]

14. Di Blasi, C. Modeling chemical and physical processes of wood and forest fuel pyrolysis. Prog. Energy Combust. Sci. 2008, 34, 47-90. [CrossRef]

15. Radmanesh, R.; Courbariaux, Y.; Chaouki, J.; Guy, C. A unified lumped approach in kinetic modeling of forest fuel pyrolysis. Fuel 2006, 85, 1211-1220. [CrossRef]

16. Amutio, M.; Lopez, G.; Alvarez, J.; Moreira, R.; Duarte, G.; Nunes, J.; Olazar, M.; Bilbao, J. Pyrolysis kinetics of forestry residues from the Portuguese Central Inland Region. Chem. Eng. Res. Des. 2013, 91, 2682-2690. [CrossRef]

17. Safdari, M.S.; Amini, E.; Weise, D.R.; Fletcher, T.H. Comparison of pyrolysis of live wildland fuels heated by radiation vs. convection. Fuel 2020, 268, 117342. [CrossRef]

18. Safdari, M.S.; Rahmati, M.; Amini, E.; Howarth, J.E.; Berryhil, J.P.; Dietenberger, M.; Weise, D.R.; Fletcher, T.H. Characterization of pyrolysis products from fast pyrolysis of live and dead vegetation native to the Southern United States. Fuel 2018, 229, 151-166. [CrossRef]

19. Anca-Couce, A.; Zobel, N.; Berger, A.; Behrendt, F. Smouldering of pine wood: Kinetics and reaction heats. Combust. Flame 2012, 159, 1708-1719. [CrossRef]

20. Benkorichi, S.; Fateh, T.; Richard, F.; Consalvi, J.-L.; Nadjai, A. Investigation of thermal degradation of pine needles using multi-step reaction mechanisms. Fire Saf. J. 2017, 91, 811-819. [CrossRef]

21. Cancellieri, D.; Innocenti, E.; Leroy-Cancellieri, V. WinGPYRO: A software platform for kinetic study of forest fuels. Fire Saf. J. 2013, 58, 103-111. [CrossRef]

22. Svenson, J.; Pettersson, J.B.C.; Davidsson, K.O. Fast pyrolysis of the main components of birch wood. Combust. Sci. Technol. 2004, 176, 977-990. [CrossRef]

23. Engstrom, J.D.; Butler, J.K.; Smith, S.G.; Baxter, L.L.; Fletcher, T.H.; Weise, D.R. Ignition behavior of live California chaparral leaves. Combust. Sci. Technol. 2004, 176, 1577-1591. [CrossRef]

24. McAllister, S.; Grenfell, I.; Hadlow, A.; Jolly, W.M.; Finney, M.; Cohen, J. Piloted ignition of live forest fuels. Fire Saf. J. 2012, 51, 133-142. [CrossRef]

25. Jolly, W.M.; Parsons, R.A.; Hadlow, A.M.; Cohn, G.M.; McAllister, S.S.; Popp, J.B.; Hubbard, R.M.; Negron, J.F. Relationships between moisture, chemistry, and ignition of Pinus contorta needles during the early stages of mountain pine beetle attack. For. Ecol. Manag. 2012, 269, 52-59. [CrossRef]

26. McAllister, S.; Finney, M. Convection Ignition of Live Forest Fuels. Fire Saf. Sci. 2014, 11, 1312-1325. [CrossRef]

27. Fletcher, T.H.; Pickett, B.M.; Smith, S.G.; Spittle, G.S.; Woodhouse, M.M.; Haake, E.; Weise, D.R. Effects of Moisture on Ignition Behavior of Moist California Chaparral and Utah Leaves. Combust. Sci. Technol. 2007, 179, 1183-1203. [CrossRef]

28. Pickett, B.M.; Isackson, C.; Wunder, R.; Fletcher, T.H.; Butler, B.W.; Weise, D.R. Experimental measurements during combustion of moist individual foliage samples. Int. J. Wildland Fire 2010, 19, 153-162. [CrossRef]

29. Mindykowski, P.; Fuentes, A.; Consalvi, J.L.; Porterie, B. Piloted ignition of wildland fuels. Fire Saf. J. 2011, 46, 34-40. [CrossRef]

30. Reszka, P.; Cruz, J.J.; Valdivia, J.; Gonzalez, F.; Rivera, J.; Carvajal, C.; Fuentes, A. Ignition delay times of live and dead pinus radiata needles. Fire Saf. J. 2020, 112, 102948. [CrossRef]

31. Borujerdi, P.; Shotorban, B.; Mahalingam, S. A computational study of burning of vertically oriented leaves with various fuel moisture contents by upward convective heating. Fuel 2020, 276, 118030. [CrossRef] 
32. Gallacher, J.R.; Lansinger, V.; Hansen, S.; Jack, D.; Weise, D.R.; Fletcher, T.H. Effects of season and heating mode on ignition and burning behavior of three species of live fuel measured in a flatflame burner system. In Proceedings of the Western States Section of the Combustion Institute Spring Technical Meeting, Tulsa, OK, USA, 16-18 March 2014; pp. 530-543.

33. Borujerdi, P.R.; Shotorban, B. Pyrolysis and Combustion Characteristics of Leaf-like Fuel under Convection and Radiation Heating. Combust. Sci. Technol. 2021, 1-23. [CrossRef]

34. Qingmin, M.; Xiaoping, C.; Daoyin, L. Numerical simulation of pyrolysis of a wood particle. Proc. CSEE 2012, $32,61-66$.

35. Li, X.; Yin, C.; Knudsen Kær, S.; Condra, T. A detailed pyrolysis model for a thermally large biomass particle. Fuel 2020, 278, 118397. [CrossRef]

36. Ding, Y.; Wang, C.; Lu, S. Modeling the pyrolysis of wet wood using FireFOAM. Energy Convers. Manag. 2015, 98, 500-506. [CrossRef]

37. Hostikka, S.; Matala, A. Pyrolysis model for predicting the heat release rate of birch wood. Combust. Sci. Technol. 2017, 189, 1373-1393. [CrossRef]

38. Kukhar, I.V.; Orlovskiy, S.N.; Martynovsakaya, S.N. Forest fires environmental impact study. IOP Conf. Ser. Earth Environ. Sci. 2020, 548, 052061. [CrossRef]

39. Samsonov, Y.N.; Ivanov, V.A.; McRae, D.J.; Baker, S.P. Chemical and dispersal characteristics of particulate emissions from forest fires in Siberia. Int. J. Wildland Fire 2012, 21, 818-827. [CrossRef]

40. Chen, J.; Li, C.; Ristovski, Z.; Milic, A.; Gu, Y.; Islam, M.S.; Wang, S.; Hao, J.; Zhang, H.; He, C.; et al. A review of forest fuel burning: Emissions and impacts on air quality, health and climate in China. Sci. Total Environ. 2017, 579, 1000-1034. [CrossRef]

41. Simoneit, B.R. Forest fuel burning-A review of organic tracers for smoke from incomplete combustion. Appl. Geochem. 2002, 17, 129-162. [CrossRef]

42. Makarov, V.I.; Popova, S.A.; Dubtsov, S.N.; Plohotnichenko, M.E. Spectrum of sizes and chemical composition of smoke emission under UV irradiation in the mode of smoldering combustion of forest materials. Interexpo Geo-Sib. 2018, 4, 196-201. (In Russian)

43. Barboni, T.; Leonelli, L.; Santoni, P.-A.; Tihay-Felicelli, V. Aerosols and carbonaceous and nitrogenous compounds emitted during the combustion of dead shrubs according to twigs' diameter and combustion phases. Fire Saf. J. 2020, 113, 102988. [CrossRef]

44. Aseeva, R.M.; Than, B.D.; Serkov, B.B.; Sivenkov, A.B. The release of smoke during thermal decomposition and combustion of wood. Leśn. Vestn. 2004, 2, 99-103. (In Russian)

45. Guo, L.; Ma, Y.; Tigabu, M.; Guo, X.; Zheng, W.; Guo, F. Emission of atmospheric pollutants during forest fire in boreal region of China. Environ. Pollut. 2020, 264, 114709. [CrossRef]

46. Urbanski, S. Wildland fire emissions, carbon, and climate: Emission factors. For. Ecol. Manag. 2014, 317, 51-60. [CrossRef]

47. Kulacki, F.A.; Acharya, S.; Chudnovsky, Y.; Cotta, R.M.; Devireddy, R.; Dhir, V.K.; Mengüç, M.P.; Mostaghimi, J.; Vafai, K. Handbook of Thermal Science and Engineering; Springer: Berlin/Heidelberg, Germany, 2018; p. 3043.

48. Samarskii, A.A. The Theory of Difference Schemes; Marcel Dekker, Inc.: New York, NY, USA; Basel, Switzerland, $2001 ;$ p. 761.

49. Samarskii, A.A.; Vabishchevich, P.N. Computational Heat Transfer, 1: Mathematical Modelling; Wiley: Chichester, UK, 1995.

50. Samarskii, A.A.; Vabishchevich, P.N. Computational Heat Transfer, 2: The Finite Difference Method; Wiley: Chichester, UK, 1995.

51. Grishin, A.M. Conjugated problems of heat and mass exchange and the physico-mathematical theory of forest fires. Inzhenerno-Fizz Zhurnal 2001, 74, 48-52.

52. Baranovskiy, N.V.; Kirienko, V.A. Mathematical simulation of heat and mass transfer during forest fuel pyrolysis caused by high temperature from crown forest fire. Int. Rev. Model. Simul. 2020, 13, 223-233. [CrossRef]

53. Korobeinichev, O.P.; Paletsky, A.A.; Gonchikzhapov, M.B.; Shundrina, I.K.; Chen, H.; Liu, N. Combustion chemistry and decomposition kinetics of forest fuels. Procedia Eng. 2013, 62, 182-193. [CrossRef]

54. Larikova, Y.S.; Kondrat'ev, M.N. Physiology of Woody Plants; BIBCOM: Moscow, Russia, 2017; p. 230. (In Russian)

55. Baranovskiy, N.V. Mathematical Modeling of the Most Probable Scenarios and Conditions for the Occurrence of Forest Fires. Ph.D. Thesis, Tomsk State University, Tomsk, Russia, 2007; 153p. (In Russian).

56. Baranovskiy, N.; Malinin, A. Mathematical simulation of forest fire impact on industrial facilities and wood-based buildings. Sustainability 2020, 12, 5475. [CrossRef]

57. Baranovskiy, N.; Demikhova, A. Mathematical modeling of heat transfer in an element of combustible plant material when exposed to radiation from a forest fire. Safety 2019, 5, 56. [CrossRef]

58. Podolskaya, A.S.; Ershov, D.V.; Shulyak, P.P. Application of the method for assessing the probability of forest fires in ISDMRosleskhoz. Mod. Probl. Remote Sens. Earth Space 2011, 8, 118-126. (In Russian)

59. Grishin, A.M.; Dolgov, A.A.; Zima, V.P.; Subbotin, A.N.; Tsvyk, R.S.H. Experimental and theoretical investigation of the effect of radiation and combined heat transfer on initiation and spread of ground forest fires. Heat Transf. Res. 2002, 33, 502-514. [CrossRef]

60. Perminov, V.A.; Marzaeva, V.I. Mathematical Modeling of Crown Forest Fire Spread in the Presence of Fire Breaks and Barriers of Finite Size. Combust. Explos. Shock Waves 2020, 56, 332-343. [CrossRef]

61. Strokatov, A.A. Physical Modeling of Fire and Heat Tornadoes. Ph.D. Thesis, Tomsk State University, Tomsk, Russia, 2007; 20p. (In Russian).

62. Grishin, A.M.; Golovanov, A.N.; Kolesnikov, A.A.; Strokatov, A.A.; Tsvyk, R.S. Experimental investigation of the thermal and fire tornadoes. Dokl. Akad. Nauk 2005, 400, 618-620.

63. Stavrova, N.I.; Gorshkov, V.V.; Katjutin, P.N.; Bakkal, I.J. The structure of northern siberian spruce-scots pine forests at different stages of post-fire succession. Forests 2020, 11, 558. [CrossRef] 
64. Baranovskiy, N.V.; Zakharevich, A.V. Experimental investigation of processes of typical forest fuel ignition by a high-temperature steel particle. Heat Transf. Res. 2016, 47, 681-689. [CrossRef]

65. GIS Meteo. Available online: https://www.gismeteo.ru/diary/4804/ (accessed on 28 February 2021).

66. Badmaev, N.; Bazarov, A. Correlation analysis of terrestrial and satellite meteodata in the territory of the Republic of Buryatia (Eastern Siberia, Russian Federation) with forest fire statistics. Agric. For. Meteorol. 2021, 297, 108245. [CrossRef]

67. Badmaev, N.B.; Bazarov, A.V.; Sychev, R.S. Forest Fire Danger Assessment Using Meteorological Trends: Case Study. In Predicting, Monitoring, and Assessing Forest Fire Dangers and Risks; Baranovskiy, N.V., Ed.; IGI Global: Hershey, PA, USA, 2020; pp. 183-208. [CrossRef]

68. Yankovich, E.P.; Yankovich, K.S.; Baranovskiy, N.V.; Bazarov, A.V.; Sychev, R.S.; Badmaev, N.B. Mapping of vegetation cover using Sentinel-2 to estimate forest fire danger. Proc. SPIE—Int. Soc. Opt. Eng. 2019, 11152, 1115216. [CrossRef]

69. Komarov, K.L.; Kachinsky, V.A. Modeling of emergency response processes on railway transport. Transp. Ural. 2011, 2, 25-30. (In Russian)

70. Grunstra, M.R.; Martell, D.L. A history of railway fires in Ontario's forests. For. Chron. 2014, 90, 314-320. [CrossRef]

71. Baranovskiy, N.V. Predicting, Monitoring, and Assessing Forest Fire Dangers and Risks; IGI Global: Hershey, PA, USA, 2020. [CrossRef]

72. Zharikova, M.V. Dynamic Spatial-Distributed Fire Risk Analysis. In Predicting, Monitoring, and Assessing Forest Fire Dangers and Risks; Baranovskiy, N.V., Ed.; IGI Global: Hershey, PA, USA, 2020; pp. 101-120. [CrossRef]

73. Yankovich, E.P.; Yankovich, K.S. Dynamic of coniferous forests areas in Baikal Region by classification of Landsat time series. Proc. SPIE Int. Soc. Opt. Eng. 2020, 11534, 1153414. [CrossRef]

74. RAD Studio. Available online: https://www.embarcadero.com/ru/ (accessed on 28 February 2021).

75. Yankovich, K.S.; Yankovich, E.P.; Baranovskiy, N.V. Classification of Vegetation to Estimate Forest Fire Danger Using Landsat 8 Images: Case Study. Math. Probl. Eng. 2019, 2019, 6296417. [CrossRef]

76. Müller, M.M.; Vilà-Vilardell, L.; Vacik, H. Towards an integrated forest fire danger assessment system for the European Alps. Ecol. Inform. 2020, 60, 101151. [CrossRef]

77. Bentekhici, N.; Bellal, S.-A.; Zegrar, A. Contribution of remote sensing and GIS to mapping the fire risk of Mediterranean forest case of the forest massif of Tlemcen (North-West Algeria). Nat. Hazards 2020, 104, 811-831. [CrossRef]

78. ArcGIS Online. Available online: https://www.arcgis.com/index.html (accessed on 28 February 2021).

79. QGIS Project. Available online: https://qgis.org/ru/site/ (accessed on 28 February 2021).

80. Pasko, O.A.; Kovyavin, V.F.; Lebedeva, N.A. The Influence of Fires on Forest Ecosystems. In Predicting, Monitoring, and Assessing Forest Fire Dangers and Risks; Baranovskiy, N.V., Ed.; IGI Global: Hershey, PA, USA, 2020; pp. 345-366. [CrossRef]

81. Cantu, M. Object Pascal Handbook; Embarcadero Technologies: Piacenza, Italy, 2020; p. 773.

82. Baranovskiy, N.V. Forest fire danger assessment using SPMD-model of computation for massive parallel system. Int. Rev. Model. Simul. 2017, 10, 193-201. [CrossRef]

83. Cyberia Supercomputer. Available online: https:/ / cyberia.tsu.ru/ (accessed on 28 February 2021).

84. Research Computing Center. Lomonosov Moscow State University. Available online: https://rcc.msu.ru/en (accessed on 28 February 2021). 